\title{
1. At the European intersection: the Austrian way to equality, diversity and inclusion
}

\author{
Isabella Scheibmayr and Astrid Reichel
}

\section{INTRODUCTION}

Austria, located in the centre of Europe, provides a good example for how equality, diversity and inclusion (EDI) are tied to historical and institutional contexts. Now a member of the European Union, Austria was once a multi-national empire, spanning large parts of Europe, its history entangled with many other European countries. Even though the importance of such a context is apparent, much diversity research tends to have a universalistic bias often based on US research (Klarsfeld, 2010; Klarsfeld et al., 2014; Klarsfeld et al., 2019). Comparative research on equality, diversity and inclusion policies that takes context into account mostly relies on classifying the context into rough categories such as liberal versus coordinated market economies and culture clusters or using singular quantitative factors like weeks of maternity leave (cf. Grosvold \& Brammer, 2011; Terjesen et al., 2015). While facilitating comparison, these categories and single measures miss the contextual variation within one country category and cannot capture details in legislation or more complex implementation processes in which multiple actors interact. To get a more complete picture of how and why equality legislation and diversity discourses are interacting, a systematic consideration of the context, a process-oriented analysis that considers the specific actors involved, is necessary. We will add to a more comprehensive perspective on equality legislation by analysing how actors and contexts influence the processes of legislation, evaluate how institutional aspects, such as legal regulation, are important incentives for EDI practices in organizations and consider the constitutive effect of implementation for legislation effectiveness and therefore for equality outcomes.

We conceptualize context as being negotiated and implemented by multiple actors creating a historically contingent social space (Özbilgin \& Tatli, 2011). Multiple actors with diverse, partly divergent intentions and political realities (i.e. social partners, diversity managers, legal professionals) are competing for symbolic power (Bourdieu, 1977, 1984) and struggling to maintain legitimacy (Greenwood et al., 2002). As Özbilgin and Tatli (2011) uncovered, the interplay between those actors over time leads to specific EDI outcomes, which become meaningful when analysing the processes of policy design and implementation (Jackson, 2010). While building on Bourdieu's actor conception, we consider the wider field surrounding the EDI field to capture actors not usually explicitly and exclusively occupied with EDI legislation (cf. Dobbin et al., 2011; Özbilgin \& Tatli, 2011) and institutional responses to legal changes. Such a context lens to EDI policy focuses on how involved actors interpret EDI as organizational practices and how policies are implemented and negotiated within specific discursive environments (Tatli, 2011). In order to explain how equality, diversity and inclusion become contested concepts (van den Brink et al., 2010; Verloo, 2007) and how inequality is co-produced in a field and in relation with the structural context of organizations (Acker, 
1990; Rubery \& Grimshaw, 2015), we consider multiple actors and their political interests and historical particularities (Calás \& Smircich, 1999).

We present the Austrian case to contribute to a contextual perspective on equality, diversity and inclusion. Austria is a characteristic example for the civil law context of continental Europe, with many powerful institutionalized actors addressing the domain of work, and with legal regulations concerning EDI that are unique, even though Austria's equality legislation is integrated within the European Union. To shed light on the state of EDI in Austria, we utilized a document analysis to investigate one of these unique legal regulations, the requirement for employers to state minimum pay in job advertisements that was introduced in 2011 through amendments of the Equal Treatment law. This legal regulation was introduced to decrease the gender pay gap in Austria, one of the highest in the EU (Eurostat, 2016). We embed this empirical case within the historical development of EDI legislation in Austria and its multi-actor context (Özbilgin \& Tatli, 2011). Following the process of legislation from draft law to implementation answers the call to adapt more historically anchored and process-oriented approaches (Jackson, 2010). The interplay of actors led to a specific discursive framing of EDI legislation in the Austrian context, with consequences not anticipated by policy makers. This helps us to shed light on the role of the institutional context and the relevant actors in the quest for equality, diversity and inclusion.

\section{THE DEVELOPMENT OF EQUALITY, DIVERSITY AND INCLUSION LEGISLATION IN AUSTRIA}

\section{From the Revolution of 1848 in the Austrian Empire to the Post-World War II Period}

Both Austria's geographic location within Europe and its history as a multi-nation empire influenced the development of equality legislation in Austria (Mayrhofer, 1995). As in many European countries, inequality, exclusion and homogeneity had been codified in the legal architecture for many decades (Flossmann \& Neuwirth, 2017; Hauch, 1990). A first uprising was the revolution in spring 1848 when students, religious groups and women demanded equality and inclusion in the form of liberal rights, e.g. freedom of speech, equality of confessions and democratic representation (Hauch, 1990; Luther \& Müller, 2013). In the Austrian empire, by then a multi-nation state spanning large parts of Europe, the ideal of equality and (political) inclusion resonated well with the ethnically diverse population. Protests all over the empire climaxed in the barricade night of 26 May 1848, the peak of the Vienna Revolution. Advocates of the women's movement participated in the demonstrations and demanded equal voting rights independent of class and gender (Hauch, 2007). The revolution, however, was violently ended in autumn, martial law established and a period of neo-absolutism followed in Austria until 1867 (Hauch, 1990).

In December 1867, a constitution for Cisleithania ${ }^{1}$ was passed and it included an equality mandate: 'before the law all citizens are equal'. Due to the gendered nature of the German language and the political realities at the time, however, it was not clear if women were included in this notion or not. Early constitutionalism, as this period was termed, established a 'relative notion of equality' - women were excluded from public office, were forbidden to form political societies and had no voting rights, and legal differences by social class, ethnicity and religion persisted as well (Flossmann \& Neuwirth, 2017). 
At the turn of the century, the so-called old women's movement used the equality principle formulated in the constitution of 1867 as an anchor to justify their demand for full equality between men and women. Their demands included active and passive voting rights, access to all levels and fields of education, to public office and political mandates, equal access to all professions and jobs, equal pay for equal work, reduction of working time, better working conditions and a reform of the Austrian Code Civil (ABGB) to establish equality within marriage and the family. Although women's rights groups in Austria were more divided, less radical and less integrated within a broader societal movement than in other European countries (e.g. the UK, France), the old women's movement gained a lot of ground in the areas of education and the right to vote, which was granted in 1918/1919. In the spheres of work, however, regulations framed as protecting women inscribed unequal access to professions and occupational fields (e.g. the prohibition of night work for women in industrial jobs) (Flossmann \& Neuwirth, 2017; Hauch, 2009).

The defeat in World War I marked the end of the Austro-Hungarian Empire, and the destruction of the Austrian Empire was interpreted as a failure of the multi-nation state, exacerbating existing nationalist and anti-Semitic attitudes within Austria (Pulzer, 2004). In the period of Austro-Fascism (1933-1938), the democratic institutions were eliminated, and an authoritarian constitution of a corporatist state established (Thorpe, 2013). Inequalities based on social class, gender, ethnicity, religion and disability were inscribed into law. National-socialist rule (1938-1945) followed this regime. Inequality based on ascriptive dimensions, especially the ideology of race, was the basis of the national-socialist regime and the totalitarian state apparatus violently enforced inequalities and exclusion in all areas of life, and systematically persecuted Jews, Communists, Roma and Sinti, people with disabilities, homosexuals, Catholics and Jehovah's Witnesses. The destructive and inhuman treatment of different groups within this regime culminated in a catastrophic world war and an incommensurable genocide of the Jewish population, the Holocaust (Beller, 2006).

\section{From the Economic Revival in the 1950s to Austria's Accession to the EU in 1995}

After World War II, Austria fast revived its economy with help from the Marshall Plan. In international relations, Austria established its new role as a neutral state, building a bridge between the Western European NATO and the Eastern European Communist countries (Beller, 2006). The state re-established the constitution from 1929, resuming the equality principle in Article 7, where it is located to this day: 'all citizens are equal before the law. Privileges by birth, sex/gender, status, class and (religious) denomination are precluded.' However, unequal treatment was still legal when 'objectively justified' until the 1970s, in part cancelling out the equality principle (Beller, 2006; Uhl, 2001).

After 1968, a students' movement, an anti-war movement and the so-called new women's movement formed. Following the election of a socialist majority government in 1971, their demands were (partly) translated into legislation (Bendl et al., 2010; Hofmann \& Bendl, 2014). The Equal Treatment Law (ETL), the core of equality legislation to this day, was passed in 1979 in the course of socialist reforms. From then on, a number of gender equality laws were passed, and later extended to cover other diversity dimensions, such as ethnicity, religion, disability and sexual orientation. Table 1.1 gives an overview of the development within the Austrian legislation since the 1970s with a focus on gender equality legislation. 
Table 1.1 Legal changes in (gender) equality legislation in Austria, 1970s until 1995

\begin{tabular}{|c|c|}
\hline Year & Legislation \\
\hline 1973 & Universal maternity compensation (Karenzgeld) introduced \\
\hline \multirow[t]{2}{*}{1975} & $\begin{array}{l}\text { Family reform (legal authority of men within family, in place since 1811, abolished and replaced by the partnership } \\
\text { principle) }\end{array}$ \\
\hline & Abortion de-criminalized (within three months or medical/criminological indication) \\
\hline 1976 & Law concerning alimony advanced \\
\hline 1977 & Maternity protection (Mutterschutz) expanded to 16 weeks \\
\hline 1978 & Civil rights subjectivity of women independent of their husbands established \\
\hline 1979 & Equal Treatment Law (ETL) (Gleichbehandlungsgesetz) for privately-owned organizations introduced \\
\hline 1982 & Convention on the Elimination of all Forms of Discrimination Against Women (UN CEDAW) ratified \\
\hline 1989 & Rape within marriage classified as a criminal act \\
\hline \multirow[t]{2}{*}{1990} & $\begin{array}{l}\text { Maternity leave (Mütterkarenz) and compensation (Karenzgeld) expanded to parental leave (Elternkarenz) - equal } \\
\text { entitlement for fathers }\end{array}$ \\
\hline & Priority of sons in the succession of (ancestral) farms repealed \\
\hline 1991 & Committee for equal opportunity (Arbeitskreis für Gleichbehandlungsfragen) introduced in universities \\
\hline \multirow[t]{2}{*}{1992} & Prohibition of night work for women repealed \\
\hline & Sexual harassment classified as a criminal act \\
\hline \multirow[t]{2}{*}{1993} & Federal Equal Treatment Law (F-ETL) for public institutions (Bundes-Gleichbehandlungsgesetz) introduced \\
\hline & Gender segregation in handicraft education (Werkunterricht) repealed \\
\hline 1994 & Law regulating the use of names amended (women are allowed to keep their last names) \\
\hline
\end{tabular}

Austria joined the European Union in 1995 and since then has adjusted its legal framework to comply with European community law. Along with the ratification of the UN CEDAW Convention in 1982, this built momentum for equality and inclusion policy in Austria (Greif \& Ulrich, 2019; Holzleithner, 2002). The introduction of the European Union's Charter of Fundamental Rights in 2009 advanced equality legislation by bringing international standards to Austria. For example, intersectionality found its way into the state's legislation by introducing the term 'multiple discrimination' (Greif \& Ulrich, 2019). Table 1.2 gives an overview of milestones in gender equality legislation in Austria since 1995.

\section{Recent Developments in EDI Legislation in the Sphere of Work}

Laws concerning EDI are dispersed and found in a variety of areas (e.g. inheritance law, criminal law, etc.). In the sphere of work, there are two central laws, the Equal Treatment Law (ETL) targeting privately-owned organizations and the Federal Equal Treatment Law (F-ETL) for the public sector (Greif \& Ulrich, 2019; Holzleithner, 2002). First introduced in 1979 (resp. 1993) and regularly amended since then, the ETL protects individuals from discrimination along five equality dimensions - (1) gender, (2) ethnicity, ${ }^{3}$ (3) religion and world view (Weltanschauung), (4) sexual orientation and (5) age. Protection from discrimination due to disability is regulated in separate laws. These equality dimensions were adapted after EU directive 2011/95/EU, which included sexual orientation and widened the definition of gender discrimination to include gender identity and sexual harassment (European Union Agency for Fundamental Rights, 2015). Social class as a basis for discrimination is missing in the ETL, even though this dimension is mentioned in the constitution.

The ETL constitutes different degrees of legal protection for each equality dimension. For gender and ethnicity, the ETL ensures anti-discrimination in the labour market, in the workplace and equal access to goods and services. Anti-discrimination in the housing market 
Table 1.2 Milestones in Austrian (gender) equality legislation since 1995

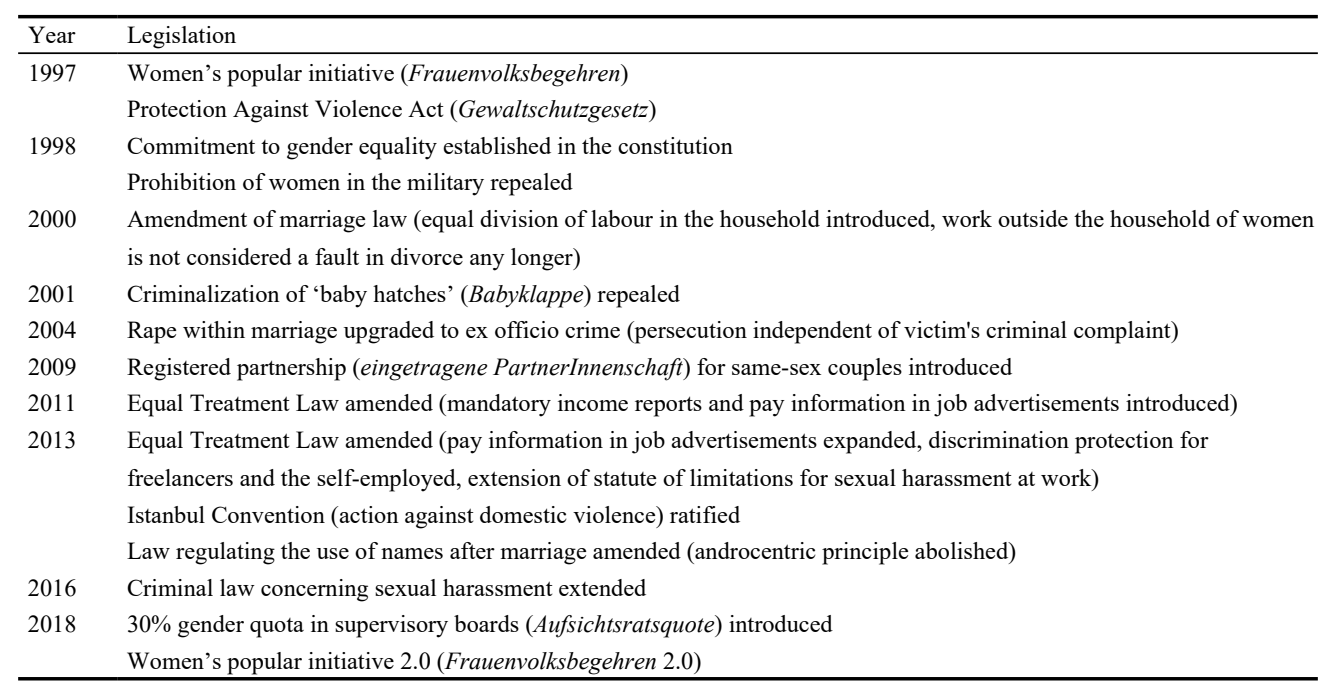

is legally regulated only for the dimension ethnicity. Unequal treatment due to sexual orientation, age and religion is solely prohibited in the labour market. Federal Disability Employment Law grants special protection (e.g. from dismissal) and access to specific public services to persons with a degree of disability of $50 \%$ or higher (Greif \& Ulrich, 2019).

In the public sector, Austria has introduced gender budgeting at the constitutional level in 2009 , obligating the state to create taxation and spending systems that aim at increasing gender equality by reducing material inequalities based on gender (Greif \& Ulrich, 2019; Klatzer et al., 2012; Schratzenstaller, 2008). Austria is one of the few countries in the world that uses this instrument and only one of three that established it in the constitution (UN, 2019). There are, however, no sanctions for non-compliance. In academia there is a form of quota regulation, a so-called tie-breaking rule in recruiting, i.e. when a man and a woman are equally qualified, the woman candidate will be preferred for the job (BGBl. Nr. 74, 1995). Additionally, many public organizations are obligated to establish an equal treatment office that oversees all HRM processes (Auer \& Welte, 2007).

In the private sector, Austria has amended the ETL in 2011 and introduced two new instruments to reach equality: mandatory pay information in job postings and mandatory equality reports for organizations of a certain size. ${ }^{4}$ Non-compliance is fined with 360 Euros in the case of job advertisements, in the case of equality reports there are no sanctions. In 2018, Austria has introduced a gender quota for the supervisory board (Austria has a two-tier board system) of publicly traded companies. This quota is considered 'symbolic equality legislation' as only a few organizations are covered ${ }^{5}$ and sanctions (empty seat) are rather low (Reichel et al., 2020). 


\section{EQUALITY AND DIVERSITY OUTCOMES}

Despite sophisticated legal regulations aiming at increasing equality and inclusion, actual numbers show that inequalities are persisting especially in the area of work (Kreimer, 2009). Women and men reached equality in the spheres of education and health, while inequality persists in the workplace and political representation (see Eurostat, 2016; ILO, 2017; Sauer, 2007; WEF, 2018). Austria follows a male-breadwinner/female-secondary earner model (Sainsbury, 1999) within a conservative welfare regime (Esping-Andersen, 1990). Additionally, Austria lags behind other EU countries regarding inclusion independent of social class and ethnicity within the education system and in the workforce (Krause \& Liebig, 2011) and correspondence studies find high levels of discrimination concerning sexual orientation and religion (Weichselbaumer, 2003, 2017). There are a number of exceptions to the anti-discrimination principle in terms of age ${ }^{6}$ and disability (Naue, 2006). These persisting inequalities (Kreimer, 2009) stand in stark contrast to Austria's elaborate EDI legislation. In past research (Appelt, 1998; Gresch \& Sauer, 2018) this paradox was explained with the interaction of two powerful institutions: traditional gender roles and historically male-dominated social partners. Therefore, in the next section, we turn to the main actors comprising the Austrian context.

\section{ACTORS IN THE FIELD OF EQUALITY, DIVERSITY AND INCLUSION IN AUSTRIA}

\section{The Legislative Body (Regulators)}

Austria is a centralist federation (Erk, 2004) with a presidential parliamentary system (Roper, 2002; Shugart, 2005). The legislative body consists of a national council (183 members elected by proportional electoral system) and a federal council (61 delegates from the nine states). Like most continental European countries, Austria follows a civil law tradition (Merryman \& Pérez-Perdomo, 2007). The judicial bodies are organized in two areas - civil law and public law with two highest courts, the Supreme Court of Justice and the Constitutional Court. The European Court of Justice (ECJ) and, in the case of human rights violations, the European Court of Human Rights (ECHR) can overturn their judicial decisions. Both European courts have been found to advance equality legislation and protection of disadvantaged groups (Greif \& Ulrich, 2019; Holzleithner, 2002).

In the legal process, the legislative, executive and judiciary branches work together. Members of the national council or the federal council, the public via popular initiative (Volksbegehren), or, most commonly, the government initiate laws. First, a parliamentary committee in the national council formulates a draft law. Then (usually) the government is introducing the draft law, and the national council discusses the draft in three consecutive rounds. There is a period of review, in which experts and the interested public can comment on the draft. This right, however, is usually only exercised by specific institutions, such as municipal governments, legal institutions, other ministries, the social partners, professional groups, NGOs and the (Catholic) Church. The national council votes on the law, while the federal council has veto power. The law is officially passed when the president has signed it. Ministries are responsible for implementing laws, while the (lower) courts decide on the 
interpretation within the legal system. The Constitutional Court rules on the constitutional lawfulness of established laws.

\section{Social Partnership - Unions and Chambers (Interest Groups)}

After World War II Austria established the social partnership, a consensus-oriented and highly institutionalized industrial relations system (Beller, 2006; Pelinka, 1987). The main social partners, the Austrian Trade Union Federation (ÖGB), Chamber of Commerce (WK), Chamber of Agriculture (LK) and Chamber of Labour (AK), voluntarily commit to economy-wide cooperation instead of following particularist interests. These social partners also interact in a highly structured wage negotiation system (Kittel, 2000): in annual collective bargaining rounds, trade unions and the chambers each representing a respective industry negotiate collective bargaining agreements for all employees and organizations within the industry. Thus, collective bargaining covers $98 \%$ of work contracts in Austria (OECD.Stat, 2018).

The social partners are also powerful actors in the legislative process and well-connected to important networks in the political parties and government agencies (Beller, 2006; Gresch \& Sauer, 2018). In the areas of trade, labour, education and social policy it was unconceivable for legislation not to be based on compromises between the social partners until the 1990s (Michalowitz \& Tálos, 2007; Tálos \& Badelt, 1999). Although their influence has decreased since the turn of the century due to globalization of political parties and the Europeanization of legislation (Michalowitz \& Tálos, 2007), the social partners are still constitutive for labour relations in Austria and play a central role in equality legislation (Gresch \& Sauer, 2015; Müller, 1986).

At the organizational level the Works Constitution Act of 1974 mandates the establishment of work councils for organizations of a certain size or if the workforce wishes to establish one (Mayrhofer, 1995). If a work council exists, its representatives have to be included in all HRM decisions (such as lay-offs and surveillance). In publicly traded companies, co-determination rights mandate the work council to be represented at the board level. It addresses all questions of discrimination and integration in the organization, except when a specific equality committee is established (Auer \& Welte, 2007).

For a long-time, empirical investigations of gender equality policies found social partners at the political level and work councils at the organizational level to be rather antagonistic to EDI initiatives. Both have been found to lack understanding and awareness of discrimination and (sometimes) even resist to implementation of equality policies, which is often explained with their historical domination by men (Gresch \& Sauer, 2018; Sauer, 2007). Empirical examples of being unaware or openly adverse to gender equality policies have been found for work councils on the organizational level (Auer \& Welte, 2007; Hönig \& Kreimer, 2005), labour unions (Blaschke \& Menrad, 2017; Kirsch \& Blaschke, 2014) and for social partners in general (Appelt, 1998; Dackweiler, 2003; Smith, 2012).

\section{Equality Experts (Professionals)}

Another group of actors in EDI legislation are equality experts. Austria has two institutions mandated by law: the Equal Treatment Commission (Gleichbehandlungskommission, ETC) and the Office for Equal Treatment (Gleichbehandlungsanwaltschaft, OET), both founded 
in 1980. They are independent government institutions located at the Federal Chancellor's Office (the head of the Austrian government). Since 2017, the OET is responsible for all equality and diversity dimensions. It advises victims of discrimination, informs about the equality legislation, and advises organizations when implementing preventive systems. In cases of pay discrimination, they have legal access to income data from the organizations and the social security systems. If discrimination is likely, the OET initiates legal proceedings with the ETC, which decides on the matter. ${ }^{7}$ The ETC is an arbitration body conducting investigations, writing a report including policy recommendations for the organization(s) involved and negotiating a settlement between the victim of discrimination and the organization. These reports have no mandatory character; however, if no settlement is reached, the report can be used as evidence in a court of law (Greif \& Ulrich, 2019; Sauer, 2007). The social partners fill the ETC's seats. Other equality experts in Austria include manifold NGOs organized along diversity dimensions, such as the Litigation Association of NGOs Against Discrimination (Klagsverband zur Durchsetzung der Rechte von Diskriminierungsopfern), the Austrian Women's Ring (Österr. Frauenring), Association of Austrian Women Jurists (Verein österr. Juristinnen), Zara (Zivilcourage und Anti-Rassismus-Arbeit), the Homosexual Initiative (HOSI) and various local NGOs representing disability rights, women's issues, migrants and refugees, and LGBT groups. Additionally, committees and expert groups within the chambers and unions, equality policy advisers and, in certain industries and large organizations, diversity managers (e.g. in banking, ICT, and producing industry, see Bendl et al., 2010) are dealing with questions of equality and inclusion.

\section{Organizations (Implementers)}

Equality legislation often addresses the state and private organizations to combat discrimination and provide provisions for excluded groups. Organizations are especially important in implementing EDI legislation, but they are also potential actors in designing legislation or at least changing potential laws. On the one hand, organizations react to institutional pressures concerning equality and integration (Eberherr, 2019; Süß \& Kleiner, 2008), on the other hand, they use different conceptions of diversity management to further their legitimacy within a specific context (Reichel et al., 2010; Tatli, 2011). Organizations might also promote EDI initiatives beyond legal compliance or engage in self-regulation (Mensi-Klarbach et al., 2019). In Austria especially multi-national organizations and large corporations have been found to be at the forefront on implementing EDI programmes and practices beyond what is legally mandated (Amstutz et al., 2018; Bendl et al., 2010; Schwarz-Woelzl \& Manahl, 2015).

\section{HRM (Implementers)}

Within organizations, HRM is the field most often associated with implementing labour and EDI legislation (Auer \& Welte, 2007; Klarsfeld et al., 2014). The implementation of legislation through HRM happens at two levels: HRM practitioners within organizations (HRM function) are tasked with implementing EDI legislation, and HRM as a community of practitioners, service providers, consultants and academics beyond organizational boundaries (HRM occupation) is concerned with interpreting EDI legislation. These two levels are closely related to each other, and both claim responsibility not only for putting equality legislation into practice, but also for creating and implementing inclusion and diversity management 
practices beyond the law (Dobbin, 2009; Klarsfeld et al., 2014; Krell et al., 2018). In Austria, equality-based HRM is traditionally influenced by other institutional actors, especially the social partners, work councils and equality experts. As a result, HRM practitioners focus on the implementation of legal regulations, employment relations and employee participation (see Reichel et al., 2009; Mayrhofer, 1995).

\section{The Scientific Community (Experts)}

There is a vibrant Austrian academic community surrounding EDI. An overview of explicit diversity management research can be found in Bendl et al. (2010) and Hofmann and Bendl (2014). Moreover, research concerning EDI is conducted in related scientific communities, such as feminist economics (Schneebaum et al., 2014; Weichselbaumer, 2017), political sciences and sociology (Aulenbacher et al., 2018; Hönig, 2016; Kirsch \& Blaschke, 2014), organization studies (Innreiter-Moser, 2005, 2016; Mensi-Klarbach, 2017) and Human Resource Management (Ortlieb \& Sieben, 2019; Reichel et al., 2009, 2010, 2013). Research on EDI is also integrated in the interdisciplinary community of gender studies researchers, institutionalized in the Austrian Gender Studies Association founded in 2012 (Gugglberger \& Hofer, 2013).

Existing studies on equality legislation concerning Austria can be categorized into three groups. First, comparative studies of equality legislation architecture considering the entire body of equality legislation and comparing countries or even whole welfare regimes (Dearing, 2016; Helfer \& Voeten, 2014; Koopmans, 2010; Lang \& Sauer, 2013). These studies identify drivers of gender equality outcomes on the macro level by classifying the context. Second, country-specific studies on equality legislation areas analyse specific fields of legislation in Austria (e.g. agriculture - Oedl-Wieser, 2015), and, third, quasi-experimental studies try to estimate effects of legal changes usually considering one specific change in legislation (e.g. voting laws in Austria - Hoffman et al., 2017).

\section{CONSTRUCTING EDI LEGISLATION IN A MULTI-ACTOR CONTEXT: PROCESS AND CONSEQUENCES}

The majority of scientific contributions from the Austrian as well as the international scientific community surrounding EDI focus on effectiveness on various levels. As a result, we know little about the legislative process and the actors involved. A more process- and actor-oriented approach, however, is important to understand puzzling or unintended effects of legal and policy changes (e.g. Antecol et al., 2018; Marx, 2019; Eveline \& Todd, 2009). Such a perspective can clarify which EDI legislation is actually passed (and which is not), how it is implemented and how this process and the actors involved are related to equality outcomes (Özbilgin \& Tatli, 2011). As equality is a contested terrain (van den Brink et al., 2010) with multiple aspects and dimensions (Calás \& Smircich, 1999) and many actors involved (Tatli, 2011), retracing a legal change in detail gives insight into the interplay of equality legislation within a specific context. Therefore, in the next section we consider the case of introducing a requirement to state pay information in job advertisements to analyse how different actors shaped the public debate as well as its implementation. 


\section{Mandatory Pay Information in Job Ads as Part of Equality Legislation}

In 2011, the Equal Treatment Law (ETL) was amended to state that employers or employment agencies are obligated to state the minimum pay (collective bargaining agreement or alternative norm) in job postings (BGBl. I Nr. 7, 2011). The intention behind the measure was to decrease the gender pay gap in Austria, one of the largest within the European Union (Eurostat, 2016; Greif \& Ulrich, 2019). Regulations about mandatory pay information in job postings are situated in the ETL section regulating the use of gender-neutral language in job postings (Greif et al., 2019). A parliamentary committee was established in 2009 to design legislation to decrease pay secrecy, following attempts by the EU to increase pay transparency (European Commission, 2014; Fagan \& Rubery, 2018). Simultaneously, the social partners discussed various options for such legislation and negotiated the terms under which they would approve any draft law. As explicated above, acquiring consent from the social partners is an unspoken requirement for ETL legislation in Austria (Gresch \& Sauer, 2015; Müller, 1986). In 2011 the law was passed and enacted in 2012 (BGBl. I Nr. 7, 2011).

Due to Austria's nearly complete collective bargaining coverage (OECD.Stat, 2018), the regulation covers the vast majority of job postings (98\%). In 2013, the law was expanded to cover all work contracts, even if there is no collective bargaining agreement (BGBl. Nr. 107, 2013). In these rare cases organizations must state the 'minimum basis for the work contract negotiations' (BGBl. Nr. 107, 2013). The legal mandate applies to all forms of job postings, including those on internal job boards and company websites, with the exemption of board positions. The first year after the introduction of the regulation was a vacatio legis, i.e. there was no penalty, giving organizations time to adjust. Afterwards, non-compliance has been punished with an administrative fine of 360 Euros, for the first offence a warning has been issued (Ulrich, 2017).

\section{Stages and Actors in the Process of Interpreting Mandatory Pay Information}

To retrace the process of constructing equality legislation as an interaction between different institutional actors within Austria, we conducted a qualitative document analysis. We followed the legal amendment from 2009 (when it was first discussed) until 2016, collecting 272 documents. Those included draft legislation, parliamentary discussions, comments on the legislation by different actors (mainly social partners and equality experts), implementation guidelines by social partners, and texts from the HRM community (professional journals, networks and service providers). We analysed the texts using a two-step deductive content analysis (Mayring, 2002). In the first step, we asked three guiding questions: (1) What gender conception is explicitly or implicitly used in the text? (2) What equality conceptions are described? (3) What EDI policy conception is used? We analysed the resulting text fragments in a second step, capturing (4) actor groups involved, (5) (discussions of) omissions in the text, and (6) framing of the GE policy. We describe our findings in temporal order to shed light on the interplay between actors in the partly institutionalized process of equality legislation and implementation of law in Austria.

Stage 1 (2009-2012): In terms of equality conceptions, in these first years we find a focus on transparency as the means for equality. The legislation clearly describes the aim of increasing information for applicants and thereby improving their position vis-à-vis (prospective) employers. The discussions in the legislative process (2009-2011) as well as the 
earliest implementation by HRM practitioners (2011-2012) show a reliance on this equality frame. The law targets the employer as being responsible for giving adequate information to applicants and prospective employees. The main actors in this stage were legislative bodies, social partners and equality experts, and later HRM practitioners. Organizations as well as the scientific community did not appear as actors, even though they were referenced in the texts, e.g. employers (organizations) were brought up frequently as the addressed of the law. The main arguments in the legislative sphere were 'fairness and transparency' (Austrian Parliament, 2010). These ideals should be ensured by obligating employers and employment agencies to state (at least) the minimum pay for an open position in order to reduce the 'wall of silence' around pay (Österreichischer Frauenring, 2010; Verein Österreichischer Juristinnen, 2010) and 'prevent that the evaluation of a job is changed ex post in a discriminatory manner' (Austrian Parliament, 2010). Therefore, the legal frame clearly follows an equal treatment approach by establishing information symmetry between employers and employees. The Chamber of Commerce and various industry interest groups tried to topple the law after it was passed and communicated their attempts in HRM media (Weissenböck, 2011). Within the HRM community the transparency aspect was tied to the business case of equality, a framing often used in Austria (Bendl et al., 2010; Mensi-Klarbach, 2012) as well as in other German-speaking countries (Bruchhagen et al., 2010; Nentwich et al., 2010). HRM practitioners discussed the regulation in terms of selection effects, i.e. pay information in job postings should help applicants who are new on the labour market to choose occupations and help HRM in terms of (self-) selection of applicants for suitable jobs. HRM practitioners also tied the regulation to standardized HRM practices, such as occupational profiles, job descriptions and compensation schemes.

Stage 2 (2012-2013): In 2013, the law was expanded to include work contracts without minimum pay determined by a collective bargaining agreement. As there was no reference point for these work contracts (i.e. no minimum pay) the legislator specified 'that pay is to be stated, that is the minimum basis for the work contract negotiations' (BGB1. Nr. 107, 2013). The term negotiation changed the framing of the equality conception immediately and significantly. The stereotype that gender and negotiation are tied together, as it has been discussed in the academic literature (Babcock \& Laschever, 2003; Bowles et al., 2005; Bowles et al., 2007), is widespread in Austria. Therefore, using the frame of negotiation changed the focus of the debate to women (as prospective applicants and potential employees) and away from employers. This frame is already visible in the comments to legislation, which state the goal to 'improve their negotiation position (...) especially of female employees' (Austrian Parliament, 2010). The main actors at this stage were legislative bodies, social partners, equality experts and the HRM community. Social partners and the HRM community were more active in this stage than in stage 1, while the legislative bodies do not appear in the text material beyond stage 2 . In the HRM community the above-mentioned frame of difference is explicitly addressed even before 2013: 'This is based mainly on the assumption that one gender negotiates better than the other' states one HR professional outlet (Rieder, 2012). The equality policy framing in stage 2 can be considered an equal opportunity approach, levelling the playing field by establishing equal starting positions.

Stage 3 (2013-2015): After the law was amended for the second time in 2013, HRM as an occupational community took responsibility for its implementation. HRM practitioners discussed the technicalities of implementation and compliance amongst themselves, sometimes with the input of social partners and equality experts. They subtly moved the equality 
framing (transparency, negotiation) to one of good HRM practice. The discussion focuses on selection effects and HRM practitioners' plea for implementation beyond the legal minimum, arguing that a realistic income should be stated in job postings (instead of only the minimum wage) in order to not deter suitable candidates. The use of income ranges is advised, so that applicants and the organization have anchors in the work contract negotiations. How different formulations might affect the outcome of (gender) equality is not debated in the HRM field. ${ }^{8}$ At this stage, HRM practitioners did not discuss stating pay information in job postings as a matter of legal compliance but of 'good HRM practice' (e.g. employer branding and talent management).

Stage 4 (after 2015): In the last stage, long after passing the law and implementing it effectively (Weissenböck, 2013), the HRM community has been discussing ways of stating pay information in job postings that can function as 'inequality-producing mechanisms', contradicting its intended purpose. We identified four such instances in our material. First, in line with implementing the regulation, one HRM practitioner stated that applicants are recently asked to state their previous income. This information is subsequently used in the selection process and during pay negotiations (Selan, 2014). Asking employees for their previous income is considered to reinforce inequality, being outlawed in certain US states for its discriminatory impact (Coghlan \& Hinkley, 2018; McNichols, 2018; Sinha, 2019). Second, HRM practitioners recount using pay information strategically in job postings to better signal to candidates if they are suitable for a position or not (Selan, 2014), reproducing existing income inequalities of groups typically affected by discrimination. Third, HRM practitioners report how pay information is used in certain cases to suppress pay negotiations (Selan, 2014), clearly oppositional to the original aim of the law (Austrian Parliament, 2010). Fourth, HRM practitioners describe how stating minimum and realistic pay differs between occupational groups (Selan, 2014), reinforcing the pay gap between occupations which typically is tightly interrelated with the workforce composition in the occupation, thus pronouncing inequality.

\section{In a Nutshell: Disappearing Equality While Framing 'Good HRM' Practice}

Summarizing our results, we can clearly see that the equality policy frame shifted its focus from transparency and fairness considerations in organizational practices to negotiation stressing the deficiencies women supposedly have during salary negotiations. This was followed by another shift to good HRM practice meaning that equality considerations are disappearing altogether and, instead, stating pay in job postings is considered from a strategic HRM perspective, i.e. by using the amendments to attract suitable employees while saving personnel costs. Also, the main actors changed throughout the process. Legislative bodies, social partners and equality experts dominated the discussion in the beginning (formulating and passing the law, start of implementation), while in the later implementation phases HRM practitioners and organizations shaped the discourse. When reading the written material chronologically and considering the Austrian historical context this process of reframing is masked by the sequential order and the interplay between the (powerful) actors in the discourse. Concerning EDI policy approaches, we find reframing from equal treatment (stage 1) to equal opportunity (stage 2) to a disappearance of equality altogether (stage 3), making inequality-producing mechanisms possible (stage 4). The focus on supposed differences in stage 2 puts the responsibility for equality on the individual level, termed a 'fix-the-woman' approach to gender equality (Kolb, 2009). In stage 4, we even find HRM practices that are associated with increasing 
inequality discussed within the context of stating pay in job postings, e.g. by asking for pay histories of applicants. The resulting frame in stage 4 is coherent with the implementation in organizations from an HRM perspective; however, it is (partly) opposing the equality-framing dominant in the legislative sphere.

Powerful semi-institutionalized actors, such as the social partners and HRM practitioners, shaped the regulation not only in the phase of drafting legislation and passing the law in the parliament, but in the stage of implementation as well. By publishing guidelines for organizations to follow, both acted as 'translators' of legislation (Scheibmayr \& Reichel, 2021). By prescribing even specific formulations, they shaped how the law was enacted in business organizations. The exemplary case shows how different actors interact in legislative processes in gender equality policy. This interaction can explain how Austria has 'the paradoxical situation of having implemented a "conservative-corporatistic" welfare state and gender regime on the one hand and a "differentiated and broad ranging corpus of gender equality legislation" (...) on the other' (Gresch \& Sauer, 2018, p. 309). There are still strong and persistent mechanisms of material inequality (Kreimer, 2009; Ziemann, 2015), while (gender) equality has become 'a crucial and defining core value of Austrian identity and principle of Austria's democracy' (Gresch \& Sauer, 2018, p. 308). So far, this paradoxical situation was explained by the interplay of high levels of institutionalization of legal equality architecture and integration within supranational law that is offset by a patriarchal industrial relation system (social partnership) and a conservative gender regime. We offer an additional explanation by showing how the interplay of actors, including those not usually considered important for EDI policy, such as HRM practitioners, by interpreting the law through their occupational and functional lens can subtly change the outcomes of equality legislation.

\section{CONCLUSION}

To conclude, we want to relate the results back to the theoretical framing and discuss the importance of considering specific historical and situational contexts, the multitude of actors involved and the interaction with the international discourse on diversity management for EDI outcomes (Klarsfeld, 2010; Klarsfeld et al., 2016; Klarsfeld et al., 2019). By using a conception of context that considers the interplay of (powerful, yet situated) actors, we are able to explain how Austria implemented a novelty in terms of EDI legislation - mandating organizations to state minimum pay in job postings. EDI discourses and the resulting policies are contingent on powerful actors with distinct interests struggling for legitimacy and competing over symbolic domination (Bourdieu, 1977). EDI legislation, however, is not only contingent on the actors of the field, but on the wider institutional context that, e.g., provides the rules processes of legislation have to follow. Despite values, norms and rules constituted in this wider context, actors in the EDI field still interpret this institutional context while playing in the field and thus shape which laws are passed and how they are implemented (Verloo, 2007). Therefore, considering the actors involved in EDI policy formulation and implementation within organizations can help explaining especially surprising or unintended (by the initiators of a law) outcomes of legal initiatives (Özbilgin \& Tatli, 2011; Tatli, 2011). Similarly, legal concepts can be implemented quite differently in varying contexts, ${ }^{9}$ and, as our case shows, countries introduce different EDI policies to reach the same outcomes. For example, in Austria the law obliges organizations to state minimum pay in job postings since 2011, while in other 
countries, e.g. in the UK, it is customary to state pay in job advertisements anyway (Gorenak et al., 2009), therefore an explicit norm is not necessary. A fine-grained analysis also allows to understand why some EDI policies are effective, while others remain merely 'symbolic' (Calás \& Smircich, 1999; van den Brink et al., 2010). By restoring the promise of equality, diversity and inclusion to its context, we work on a future where this promise can be fulfilled.

\section{NOTES}

1. The western and northern half of the empire, where the current Austrian Republic resides.

2. 'Alle Bundesbürger sind vor dem Gesetz gleich. Vorrechte der Geburt, des Geschlechtes, des Standes, der Klasse und des Bekenntnisses sind ausgeschlossen' (Article 7, Bundes-Verfassungsgesetz (B-VG)).

3. Due to its use by the Nazi regime, race as a term denoting unequal treatment due to racism is not used in German-speaking contexts in order to avoid problematic historic connotations, see UNESCO (1950) and Fischer et al. (2019). We therefore use ethnicity throughout this text.

4. Similar to the regulation in Belgium, see Workplace Gender Equality Agency (2019).

5. The law targets only publicly traded organizations (Aktiengesellschaften) listed on the stock exchange and with more than 1,000 employees. Legal experts assume that only $70-80$ organizations are covered by this regulation, see Wieser and Fischeneder (2019).

6. I.e. unequal treatment based on age can be legal if it is reasonably justified by a legitimate aim and minimum or maximum ages for entry are allowed if they do not constitute sex discrimination (Article 6, EU Directive 2000/78/EC in European Council (2000)).

7. The ETC consists of three senates: gender discrimination in the workplace, discrimination based on gender and ethnicity in other areas of life, and one for all other ETL dimensions.

8. For a recent study on how different formulations of pay in job postings affect gender differences in pay expectations in Austria see Brandl et al. (2018).

9. E.g., EU directives concerning gender equality policy are implemented quite differently in the member states, for a critical discussion see Gresch and Sauer (2015).

\section{REFERENCES}

Acker, J. (1990). Hierarchies, jobs, bodies: a theory of gendered organizations. Gender and Society, 4(2), $139-158$.

Amstutz, N., Eberherr, H., Funder, M., \& Hofmann, R. (2018). Zwischen Beharrung und Transformation: Neo-institutionalistische Reflexionen zum Gender Cage in Organisationen. In N. Amstutz, H. Eberherr, M. Funder, \& R. Hofmann (Eds), Geschlecht als widersprüchliche Institution: Neo-institutionalistische Implikationen zum Gender Cage in Organisationen (pp. 11-40). Nomos.

Antecol, H., Bedard, K., \& Stearns, J. (2018). Equal but inequitable: who benefits from gender-neutral tenure clock stopping policies? American Economic Review, 108(9), 2420-2441. https://doi.org/10 $.1257 /$ aer.20160613

Appelt, E. (1998). Women in the Austrian economy. In G. Bischof, A. Pelinka, \& E. Thurner (Eds), Contemporary Austrian studies: v. 6. Women in Austria (pp. 83-103). Routledge. https://doi.org/10 $.4324 / 9781351299084$

Auer, M., \& Welte, H. (2007). Social positioning of equal opportunity actors in Austria. Equal Opportunities International, 26(8), 778-801. https://doi.org/10.1108/02610150710836136

Aulenbacher, B., Gutiérrez Rodríguez, E., \& Liebig, B. (2018). Care work - international perspectives and reflections. Österreichische Zeitschrift Für Soziologie, 43(1), 1-5. https://doi.org/10.1007/s1 1614 -018-0291-0

Austrian Parliament (2010). Gleichbehandlungsgesetz, Gesetz über die Gleichbehandlungskommission u.a., Änderung (179/ME): Begutachtungsentwurf Erläuterungen. https://www.parlament.gv.at/ PAKT/VHG/XXIV/ME/ME_00179/fname_191828.pdf 
Babcock, L., \& Laschever, S. (2003). Women don't ask. Princeton University Press.

Beller, S. (2006). A concise history of Austria. Cambridge concise histories. Cambridge University Press. Bendl, R., Hanappi-Egger, E., \& Hofmann, R. (2010). Austrian perspectives on diversity management and equal treatment: regulations, debates, practices and trends. In A. Klarsfeld (Ed.), International handbook on diversity management at work: country perspectives on diversity and equal treatment (pp. 27-44). Edward Elgar Publishing.

BGB1. I Nr. 7. (2011). Amendment of the Equal Treatment Law, the Law concerning the Office of Equal Treatment, the Disability Hiring Law and the Federal Equal Treatment Law of the Disabled. In German. https://www.ris.bka.gv.at/Dokumente/BgblAuth/BGBLA_2011_I_7/BGBLA_2011_I_7 .pdf

BGB1. Nr. 74. (1995). 229. Verordnung: Frauenförderungsplan im Wirkungsbereich des Bundesministeriums für Wissenschaft: Plan for the advancement of women in the area of competency of the Ministry of Science, Research and Art. Vienna.

BGB1. Nr. 107. (2013). Amendment of the Equal Treatment Law, the Law concerning the Office of Equal Treatment, the Disability Hiring Law, the Federal Equal Treatment Law of the Disabled and the Contract of Employment Regulation Adjustment Law. In German. https://www.ris.bka.gv.at/eli/bgb1/ I/2013/107

Blaschke, S., \& Menrad, M. (2017). Einführung und Umsetzung gewerkschaftlicher Frauenquoten: Befunde zu zwei österreichischen Gewerkschaften. The German Journal of Industrial Relations (Industrielle Beziehungen), 24(1), 75-99.

Bourdieu, P. (1977). Outline of a theory of practice (R. Nice, trans.). Cambridge studies in social and cultural anthropology: vol. 16. Cambridge University Press. https://doi.org/10.1017/CBO9780511812507

Bourdieu, P. (1984). Distinction: a social critique of the judgement of taste (R. Nice, trans.). Routledge classics. Routledge, Taylor \& Francis Group.

Bowles, H. R., Babcock, L., \& Lai, L. (2007). Social incentives for gender differences in the propensity to initiate negotiations: sometimes it does hurt to ask. Organizational Behavior and Human Decision Processes, 103(1), 84-103. https://doi.org/10.1016/j.obhdp.2006.09.001

Bowles, H. R., Babcock, L., \& McGinn, K. L. (2005). Constraints and triggers: situational mechanics of gender in negotiation. Journal of Personality and Social Psychology, 89(6), 951-965.

Brandl, J., Yilmaz, L., \& Schönherr, B. (2018). Können Gehaltsangaben dazu beitragen, den Gender-Pay-Gap zu verringern? (Organizations \& Society Working Paper Series 03/2018). University of Innsbruck.

Bruchhagen, V., Grieger, J., Koall, I., Meuser, M., Ortlieb, R., \& Sieben, B. (2010). Social inequality, diversity and equal treatment at work: the German case. In A. Klarsfeld (Ed.), International handbook on diversity management at work: country perspectives on diversity and equal treatment (pp. 109-138). Edward Elgar Publishing.

Calás, M. B., \& Smircich, L. (1999). From 'the woman's' point of view: feminist approaches to organization studies. In S. Clegg \& C. Hardy (Eds), Studying organization: theory and method (2005 edn, pp. 212-250). SAGE. https://doi.org/10.4135/9781446218556.n8

Coghlan, E., \& Hinkley, S. (2018). State policy strategies for narrowing the gender wage gap. https:// escholarship.org/uc/item/3326v5gv

Dackweiler, R.-M. (2003). Wohlfahrtsstaatliche Geschlechterpolitik am Beispiel Österreichs: Arena eines widersprüchlich modernisierten Geschlechter-Diskurses. VS Verlag für Sozialwissenschaften. http://dx.doi.org/10.1007/978-3-663-11878-7 https://doi.org/10.1007/978-3-663-11878-7

Dearing, H. (2016). Gender equality in the division of work: how to assess European leave policies regarding their compliance with an ideal leave model. Journal of European Social Policy, 26(3), 234-247. https://doi.org/10.1177/0958928716642951

Dobbin, F. (2009). Inventing equal opportunity. Princeton University Press. https://doi.org/10.1515/ 9781400830893

Dobbin, F., Kim, S., \& Kalev, A. (2011). You can't always get what you need. American Sociological Review, 76(3), 386-411. https://doi.org/10.1177/0003122411409704

Eberherr, H. (2019). Diversity nutzen - Zum Nutzen von Diversity. Begründungs- und Legitimationsdiskurse im organisationalen Vergleich. In W. Frieß, A. Mucha, \& D. Rastetter (Eds), Diversity management und seine Kontexte: celebrate diversity?! (1st edn, pp. 23-38). Verlag Barbara Budrich. 
Erk, J. (2004). Austria: a federation without federalism. Publius: The Journal of Federalism, 34(1), 1-20. Esping-Andersen, G. (1990). The three political economies of the welfare state. International Journal of Sociology, 20(3), 92-123.

European Commission (2014). Commission Recommendation of 7 March 2014 on strengthening the principle of equal pay between men and women through transparency. Official Journal of the European Union, L69, 112-116.

European Council (2000). Council Directive 2000/78/EC of 27 November 2000 establishing a general framework for equal treatment in employment and occupation. Official Journal of the European Union(L 303), 16-22.

European Union Agency for Fundamental Rights (2015). Protection against discrimination on grounds of sexual orientation, gender identity and sex characteristics in the EU: comparative legal analysis (Update 2015). Equality/FRA, European Union Agency for Fundamental Rights. Publications Office of the European Union. http://fra.europa.eu/sites/default/files/fra_uploads/protection_against discrimination_legal_update_2015.pdf https://doi.org/10.2811/054312

Eurostat (2016). Gender overall earnings gap, 2010: update. http://ec.europa.eu/eurostat/statistics -explained/index.php/File:Gender_overall_earnings_gap,_2010_\%28\%25\%29_update.png \#filehistory

Eveline, J. \& Todd, P. (2009). Gender mainstreaming: the answer to the gender pay gap? Gender, Work \& Organization, 16(5), 536-558. https://doi.org/10.1111/j.1468-0432.2007.00386.x

Fagan, C. \& Rubery, J. (2018). Advancing gender equality through European employment policy: the impact of the UK's EU membership and the risks of Brexit. Social Policy and Society, 17(2), 297-317. https://doi.org/10.1017/S1474746417000458

Fischer, M. S., Hoßfeld, U., Krause, J., \& Richter, S. (2019). Jena Declaration: the concept of race is the result of racism, not its prerequisite. German Zoological Society, University of Jena.

Flossmann, U., \& Neuwirth, K. (2017). Frauenrechtsgeschichte und historische Geschlechterordnungen. Trauner.

Gorenak, I., Mlaker, S., \& Orthaber, S. (2009). Cross-cultural comparison of online job advertisements. Logistics \& Sustainable Transport, 2(1), 49-61.

Greenwood, R., Suddaby, R., \& Hinings, C. (2002). Theorizing change: the role of professional associations in the transformation of institutionalized fields. Academy of Management Journal, 45(1), 58-80.

Greif, E. \& Ulrich, S. (2019). Legal gender studies und Antidiskriminierungsrecht. MANZ.

Greif, E., Neuwirth, K., \& Ulrich, S. (2019). Legal gender studies und Antidiskriminierungsrecht: Rechtsquellen (11th edn). MANZ.

Gresch, N., \& Sauer, B. (2015). Topographies of gender democracy in Austria. In Y. Galligan (Ed.), States of democracy. Taylor and Francis.

Gresch, N., \& Sauer, B. (2018). The Austrian paradox: the challenges of transforming a conservative gender regime. In R. Rubio-Marín \& É. Lépinard (Eds), Cambridge studies in law and society. Transforming gender citizenship: the irresistible rise of gender quotas in Europe (pp. 308-340). Cambridge University Press.

Grosvold, J., \& Brammer, S. (2011). National institutional systems as antecedents of female board representation: an empirical study. Corporate Governance: An International Review, 19(2), 116-135. https://doi.org/10.1111/j.1467-8683.2010.00830.x

Gugglberger, M., \& Hofer, K. P. (2013). Die Gründung der Österreichischen Gesellschaft für Geschlechterforschung/Gender Studies Association (ÖGGF) - ein Bericht. L'homme, 24(2), 125-130. https://doi.org/10.7767/lhomme.2013.24.2.125

Hauch, G. (1990). Frau Biedermeier auf den Barrikaden: Frauenleben in der Wiener Revolution 1848. Verl. für Gesellschaftskritik.

Hauch, G. (2007). Gender in Wissenschaft und Gesellschaft: Von der Nützlichkeit einer Kategorie und ihrer nachhaltigen Wirkung. In M. Pammer (Ed.), Festschrift für Roman Sandgruber zum 60. Geburtstag (pp. 491-508).

Hauch, G. (2009). Frauen bewegen Politik: Österreich 1848-1938. Studien zur Frauen- und Geschlechterforschung: Vol. 10. StudienVerl.

Helfer, L. R., \& Voeten, E. (2014). International courts as agents of legal change: evidence from LGBT rights in Europe. International Organization, 68(1), 77-110. https://doi.org/10.1017/ S0020818313000398 
Hoffman, M., León, G., \& Lombardi, M. (2017). Compulsory voting, turnout, and government spending: evidence from Austria. Journal of Public Economics, 145, 103-115. https://doi.org/10.1016/j.jpubeco .2016 .10 .002

Hofmann, R. \& Bendl, R. (2014). Equal treatment in Austria: current practices and challenges. In A. Klarsfeld, L. Booysen, E. S. Ng, I. Roper, \& A. Tatli (Eds), International handbook on diversity management at work: country perspectives on diversity and equal treatment (pp. 35-45). Edward Elgar.

Holzleithner, E. (2002). Recht Macht Geschlecht: Legal Gender Studies; eine Einführung. WUV.

Hönig, B. (2016). Paradoxes of equality in European research funding for 'excellence'. In H. Staubmann (Ed.), Soziologie in Österreich - Internationale Verflechtungen (pp. 137-155). Innsbruck University Press.

Hönig, B., \& Kreimer, M. (2005). Konstellationen und Mechanismen geschlechtlicher Lohn-Diskriminierung in Österreich. Österreichische Zeitschrift Für Soziologie, 30(1), 44-66.

ILO (2017). A global snapshot: women leaders and managers in employers' organizations (Working Paper No. 17). Bureau for Employers' Activities (ACT/EMP).

Innreiter-Moser, C. (2005). Feministische Theorien und Organisationsforschung. In G. Krell (Ed.), Betriebswirtschaftslehre und Gender Studies: Analysen aus Organisation, Personal, Marketing und Controlling (pp. 83-104). Gabler.

Innreiter-Moser, C. (2016). Der betriebswirtschaftliche Nutzen von Gleichstellungsmaßnahmen. In K. Neuwirth, U. Salinger, \& J. Senk (Eds), Gleichbehandlung UNTERNEHMEN: Möglichkeiten in und für Unternehmen (pp. 13-35). Trauner.

Jackson, G. (2010). Actors and institutions. In G. Morgan, J. L. Campbell, C. Crouch, O. K. Pederson, \& R. Whitley (Eds), The Oxford handbook of comparative institutional analysis (pp. 63-86). Oxford University Press.

Kirsch, A. \& Blaschke, S. (2014). Women's quotas and their effects: a comparison of Austrian and German trade unions. European Journal of Industrial Relations, 20(3), 201-217. https://doi.org/10 $.1177 / 0959680113518231$

Kittel, B. (2000). Deaustrification? The policy-area-specific evolution of Austrian social partnership. West European Politics, 23(1), 108-129. https://doi.org/10.1080/01402380008425354

Klarsfeld, A. (2010). Perspectives from 16 countries on diversity and equal treatment at work: an overview and transverse questions. In A. Klarsfeld (Ed.), International handbook on diversity management at work: country perspectives on diversity and equal treatment (pp. 1-10). Edward Elgar Publishing.

Klarsfeld, A., Booysen, L., Ng, E. S., Roper, I., \& Tatli, A. (2014). Introduction: equality and diversity in 14 countries - analysis and summary. In A. Klarsfeld, L. Booysen, E. S. Ng, I. Roper, \& A. Tatli (Eds.), International handbook on diversity management at work: country perspectives on diversity and equal treatment (pp. 1-12). Edward Elgar.

Klarsfeld, A., Knappert, L., Kornau, A., Ngunjiri, F. W., \& Sieben, B. (2019). Diversity in under-researched countries: new empirical fields challenging old theories? Equality, Diversity and Inclusion: An International Journal, 38(7), 694-704. https://doi.org/10.1108/EDI-03-2019-0110

Klarsfeld, A., Ng, E. S., Booysen, L. A. E., Christiansen, L. C., \& Kuvaas, B. (Eds). (2016). Research handbook of international and comparative perspectives on diversity management. Edward Elgar Publishing.

Klatzer, E., Schratzenstaller, M., Buchinger, B., \& Schaffer, N. (2012). Gender budgeting in the constitution - a look at formal and real conditions in Austria. Internationale Politik Und Gesellschaft, 2, $48-64$.

Kolb, D. M. (2009). Too bad for the women or does it have to be? Gender and negotiation research over the past twenty-five years. Negotiation Journal, 25(4), 515-531. https://doi.org/10.1111/j.1571-9979 $.2009 .00242 . \mathrm{x}$

Koopmans, R. (2010). Trade-offs between equality and difference: immigrant integration, multiculturalism and the welfare state in cross-national perspective. Journal of Ethnic and Migration Studies, 36(1), 1-26. https://doi.org/10.1080/13691830903250881

Krause, K. \& Liebig, T. (2011). The labour market integration of immigrants and their children in Austria (OECD Social, Employment and Migration Working Papers No. 127). OECD. https://doi.org/ $10.1787 / 5 \mathrm{~kg} 264 \mathrm{fz} 6 \mathrm{p} 8 \mathrm{w}$-en

Kreimer, M. (2009). Ökonomie der Geschlechterdifferenz: Zur Persistenz von Gender Gaps. VS Verlag für Sozialwissenschaften. 
Krell, G., Ortlieb, R., \& Sieben, B. (2018). Gender und giversity in Organisationen: Grundlegendes zur Chancengleichheit durch Personalpolitik. Springer Gabler. https://doi.org/10.1007/978-3-658-20554 $-6$

Lang, S., \& Sauer, B. (2013). Does federalism impact gender architectures? The case of women's policy agencies in Germany and Austria. Publius: The Journal of Federalism, 43(1), 68-89. https://doi.org/ $10.1093 /$ publius/pjs048

Luther, K. R. \& Müller, W. C. (2013). Consociationalism and the Austrian political system. In K. R. Luther \& W. C. Müller (Eds), Politics in Austria: still a case of consociationalism? (pp. 1-15). Routledge.

Marx, U. (2019). Accounting for equality: Gender budgeting and moderate feminism. Gender, Work \& Organization, 26(8), 1176-1190. https://doi.org/10.1111/gwao.12307

Mayrhofer, W. (1995). Human resource management in Austria. Employee Relations, 17(7), 8-30. https://doi.org/10.1108/01425459510103424

Mayring, P. (2002). Einführung in die qualitative Sozialforschung: Eine Anleitung zum qualitativen Denken (5th edn). Beltz.

McNichols, D. (2018). Information and the persistence of the gender wage gap; early evidence from California's salary history ban. SSRN Electronic Journal. Advance online publication. https://doi.org/ $10.2139 /$ ssrn. 3277664

Mensi-Klarbach, H. (2012). Der Business Case für Diversität und Diversitätsmanagement. In R. Bendl, E. Hanappi-Egger, \& R. Hofmann (Eds), Diversität und Diversitätsmanagement (pp. 299-326). UTB $\mathrm{GmbH}$; Facultas.

Mensi-Klarbach, H. (2017). Gender diversity in Austrian boards - combing soft and hard law regulations. In C. Seierstad, P. Gabaldon, \& H. Mensi-Klarbach (Eds), Gender diversity in the boardroom: volume 2: multiple approaches beyond quotas (pp. 103-128). Springer.

Mensi-Klarbach, H., Leixnering, S., \& Schiffinger, M. (2019). The carrot or the stick: self-regulation for gender-diverse boards via codes of good governance. Journal of Business Ethics, 18(3), 487. https:// doi.org/10.1007/s10551-019-04336-Z

Merryman, J., \& Pérez-Perdomo, R. (2007). The civil law tradition: an introduction to the legal systems of Europe and Latin America (3rd edn). Stanford University Press.

Michalowitz, I., \& Tálos, E. (2007). Österreichs Interessenpolitik auf neuen Pfaden - zwischen Austrokorporatismus und Lobbying. Österreichische Zeitschrift Für Politikwissenschaft, 36(4), 369-388.

Müller, W. C. (1986). Issue transfer and symbolic legislation: a case study of the Austrian Equal Treatment Act. European Journal of Political Research, 14(1-2), 63-80. https://doi.org/10.1111/j $.1475-6765.1986 . t b 00822 . x$

Naue, U. (2006). Governing disability in Austria: reflections on a changing political field. Disability Studies Quarterly, 26(2).

Nentwich, J., Steyart, C., \& Liebig, B. (2010). Diversity made in Switzerland: traditional and new plurality meets the business case. In A. Klarsfeld (Ed.), International handbook on diversity management at work: country perspectives on diversity and equal treatment (pp. 263-282). Edward Elgar Publishing.

OECD.Stat. (2018). Collective bargaining coverage. https://stats.oecd.org/Index.aspx?DataSetCode= CBC

Oedl-Wieser, T. (2015). Gender equality: a core dimension in Rural Development Programmes in Austria? Gender, Place \& Culture, 22(5), 685-699. https://doi.org/10.1080/0966369X.2013.879103

Ortlieb, R., \& Sieben, B. (2019). Balls, barbecues and boxing: contesting gender regimes at organizational social events. Organization Studies, 40(1), 115-134. https://doi.org/10.1177/0170840617736941

Österreichischer Frauenring. (2010). Stellungnahme des Österreichischen Frauenrings zum Entwurf eines Bundesgesetzes, mit dem das Gleichbehandlungsgesetz, das Bundesgesetz über die Gleichbehandlungskommission und die Gleichbehandlungsanwaltschaft geändert werden (22/ SN-179/ME XXIV.GP). Wien.

Özbilgin, M. \& Tatli, A. (2011). Mapping out the field of equality and diversity: rise of individualism and voluntarism. Human Relations, 64(9), 1229-1253. https://doi.org/10.1177/0018726711413620

Pelinka, A. (1987). Austrian social partnership: stability versus innovation. West European Politics, 10(1), 63-75. https://doi.org/10.1080/01402388708424614 


\section{Research handbook on new frontiers of equality and diversity at work}

Pulzer, P. G. J. (2004). Die Entstehung des politischen Antisemitismus in Deutschland und Österreich 1867 bis 1914 . Vandenhoeck \& Ruprecht.

Reichel, A., Brandl, J., \& Mayrhofer, W. (2009). Departmental status in light of a growing proportion of female staff: the case of human resource management. European Journal of International Management, 3(4), 457. https://doi.org/10.1504/EJIM.2009.028850

Reichel, A., Brandl, J., \& Mayrhofer, W. (2010). The strongest link: legitimacy of top management diversity, sex stereotypes and the rise of women in human resource management 1995-2004. Management Revue, 21(3), 332-352.

Reichel, A., Brandl, J., \& Mayrhofer, W. (2013). New captain but a sinking ship? The influence of HR director's gender on the status of the HR department - a longitudinal study. In E. Parry, E. Stavrou, \& M. Lazarova (Eds), Global Trends in Human Resource Management (pp. 35-53). Palgrave Macmillan.

Reichel, A., Mayrhofer, W., \& Chudzikowski, K. (2009). Human resource development in Austria: a cultural perspective of management development. In C. D. Hansen \& Y.-T. Lee (Eds), The Cultural Context of Human Resource Development (Vol. 2, pp. 90-107). Palgrave Macmillan. https://doi.org/ $10.1057 / 97802302366606$

Reichel, A., Scheibmayr, I., \& Brandl, J. (2020). The HR-lady is on board: untangling the link between HRM's feminine image and HRM's board representation. Human Resource Management Journal. 30(4), 586-603. https://doi.org/10.1111/1748-8583.12263

Rieder, P. (2012, 4 January). Ab jetzt wirds teuer! Mindestgehälter in Inseraten. HRweb.at.

Roper, S. D. (2002). Are all semipresidential regimes the same? A comparison of premier-presidential regimes. Comparative Politics, 34(3), 253-272.

Rubery, J., \& Grimshaw, D. (2015). The 40-year pursuit of equal pay: a case of constantly moving goalposts. ILR Review, 39(2), 319-343. https://doi.org/10.1093/cje/beu053

Sainsbury, D. (1999). Gender, policy regimes, and politics. In D. Sainsbury (Ed.), Gender and welfare state regimes. Oxford University Press.

Sauer, B. (2007). What happened to the model student? Austrian state feminism since the 1990s. In J. Outshoorn \& J. Kantola (Eds), Changing state feminism (pp. 41-61). Palgrave Macmillan.

Scheibmayr, I. \& Reichel, A. (2021). Beating the advertising drum for the employer: How legal context translates into good HRM practice. Human Resource Management Journal. Early View. https://doi .org/10.1111/1748-8583.12413

Schneebaum, A., Rehm, M., Mader, K., Klopf, P., \& Hollan, K. (2014). The gender wealth gap in Europe (Department of Economics Working Paper No. 186). WU Wien.

Schratzenstaller, M. (2008). Gender budgeting in Austria. CESifo, 06(2), 44-51.

Schwarz-Woelzl, M., \& Manahl, C. (2015). Diversity and diversity management in Austria, the Czech Republic, Poland and Spain: Comparative Report.

Selan, E. (2014, 10 February). Gehaltsangaben in Inseraten - zwischen Sinn \& Augenauswischerei. HRweb.at.

Shugart, M. S. (2005). Semi-presidential systems: dual executive and mixed authority patterns. French Politics, 3(3), 323-351.

Sinha, S. (2019). Salary history ban: gender pay gap and spillover effects. SSRN Electronic Journal. Advance online publication. https://doi.org/10.2139/ssrn.3458194

Smith, M. (2012). Social regulation of the gender pay gap in the EU. European Journal of Industrial Relations, 18(4), 365-380. https://doi.org/10.1177/0959680112465931

Süß, S., \& Kleiner, M. (2008). Dissemination of diversity management in Germany. European Management Journal, 26(1), 35-47. https://doi.org/10.1016/j.emj.2007.10.003

Tálos, E., \& Badelt, C. (1999). The welfare state between new stimuli and new pressures: Austrian social policy and the EU. Journal of European Social Policy, 9(4), 351-361.

Tatli, A. (2011). A multi-layered exploration of the diversity management field: diversity discourses, practices and practitioners in the UK. British Journal of Management, 22(2), 238-253. https://doi.org/ $10.1111 / \mathrm{j} .1467-8551.2010 .00730 . \mathrm{x}$

Terjesen, S., Aguilera, R. V., \& Lorenz, R. (2015). Legislating a woman's seat on the board: institutional factors driving gender quotas for boards of directors. Journal of Business Ethics, 128(2), 233-251. https://doi.org/10.1007/s10551-014-2083-1 
Thorpe, J. (Ed.). (2013). Pan-Germanism and the Austrofascist state, 1933-38. Manchester University Press. https://doi.org/10.7765/9781847794543

Uhl, H. (2001). Das 'erste Opfer': Der österreichische Opfermythos und seine Transformationen in der Zweiten Republik. Austrian Journal of Political Science, 30(1), 19-34.

Ulrich, S. (2017). Strukturprobleme im Gleichstellungs- und Antidiskriminierungsrecht. In BM für Justiz (Ed.), Recht tolerant: RichterInnenwoche 2016 (pp. 101-116). NWV.

UN (2019). Austria: Gender budgeting. United Nations. https://www.un.org/ruleoflaw/blog/portfolio -items/austria-gender-budgeting/

UNESCO (1950). The race question (No. 791). UNESCO.

van den Brink, M., Benschop, Y., \& Jansen, W. (2010). Transparency in academic recruitment: a problematic tool for gender equality? Organization Studies, 31(11), 1459-1483. https://doi.org/10.1177/ 0170840610380812

Verein Österreichischer Juristinnen (2010). Stellungnahme des Vereins Österreichischer Juristinnen zum Entwurf eines Bundesgesetzes, mit dem das Gleichbehandlungsgesetz, das Bundesgesetz über die Gleichbehandlungskommission und die Gleichbehandlungsanwaltschaft geändert werden (20/ SN-179/ME XXIV.GP).

Verloo, M. (2007). Multiple meanings of gender equality: a critical frame analysis of gender policies in Europe. CEU Press.

WEF (2018). The Global Gender Gap Report 2018. World Economic Forum.

Weichselbaumer, D. (2003). Sexual orientation discrimination in hiring. Labour Economics, 10(6), 629-642. https://doi.org/10.1016/S0927-5371(03)00074-5

Weichselbaumer, D. (2017). Discrimination against migrant job applicants in Austria: an experimental study. German Economic Review, 18(2), 237-265. https://doi.org/10.1111/geer.12104

Weissenböck, C. (2011, 8 March). Mindestlohn im Jobinserat: Diskussion um neues Gesetz. Karriere.at.

Weissenböck, C. (2013). Mindestgehalt im Jobinserat: 96 Prozent machen Angaben. Karriere.at.

Wieser, C. \& Fischeneder, A. (2019). Frauen. Management Report 2019: Aufsichtsratsquote - das Jahr danach. Kammer für Arbeiter und Angestellte für Wien.

Workplace Gender Equality Agency (2019). International Gender Equality Reporting Schemes. https:// www.wgea.gov.au/data/wgea-research/international-gender-equality-reporting-schemes

Ziemann, V. (2015). Towards more gender equality in Austria. (OECD Economics Department Working Paper No. 1273). OECD. https://doi.org/10.1787/5jrp2s4pfbnp-en 